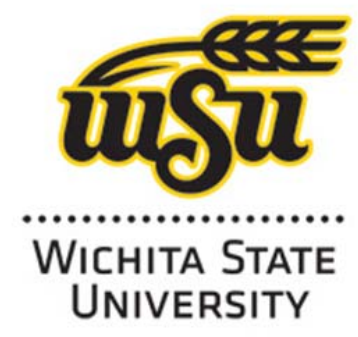

Mary LizJ ameson

\section{Wichita State University Libraries SOAR: Shocker Open Access Repository}

Biological Sciences

\title{
Synopsis of Scarab Beetle Tribe Valgini (Coleoptera: Scarabaeidae: Cetoniinae) in the New World
}

Mary LizJ ameson

University of Nebraska State Museum, maryliz.jameson@gmail.com

Katharine Anne Swoboda

Utah State University, Logan, UT 84321

Recommended citation

J ameson, Mary Liz. and Katharine Anne Swoboda. 2005. Synopsis of Scarab Beetle Tribe Valgini (Coleoptera: Scarabaeidae: Cetoniinae) in the New World. Annals of the Entomological Society of America 98(5): 658-672. 


\title{
Synopsis of Scarab Beetle Tribe Valgini (Coleoptera: Scarabaeidae: Cetoniinae) in the New World
}

\author{
MARY LIZ JAMESON ${ }^{1}$ AND KATHARINE ANNE SWOBODA ${ }^{2}$
}

Ann. Entomol. Soc. Am. 98(5): 658-672 (2005)

\begin{abstract}
Two genera and five species of valgine scarabs (Cetoniinae: Valgini) are found in the New World, including the introduced European species, Valgus hemipterus L.. Valgus mexicanus Cazier is transferred to the genus Dasyvalgus Kolbe, and characters that support this transfer are discussed. Based on shared morphological characters, Valgus minutus Casey and V. serricollis Fitch are synonymized with V. canaliculatus (Olivier). Neotypes are designated for V. serricollis Fitch and Cetonia canaliculata Olivier. A key to the genera and species of New World Valgini is provided. Species are redescribed and information about geographic and phenology, biology, and larvae is provided.
\end{abstract}

KEY WORDS Scarabaeidae, Cetoniinae, Valgini, Dasyvalgus, Valgus

VAlgine SCARABS (Coleoptera: Scarabaeidae: Cetoniinae) are small $(\approx 2.0-15.0 \mathrm{~mm})$, possess a vestiture of scale-like setae, and are most diverse in the Old World tropics. Unusual life histories and morphological traits make species in the group biologically interesting. A firm foundation in the taxonomy and systematics of the group will allow for a better understanding of evolutionary processes and patterns, including coevolutionary relationships between valgine scarabs and termites, dispersal of adventive species in the New World, and evolutionary mechanisms that affect high intraspecific variation. We provide an overview of the valgine species in the New World, thus creating the foundation for additional evolutionary research.

The tribe Valgini is comprised of $\approx 335$ species worldwide (Krajcik 1999, Antoine 2002). As characterized herein, the New World valgine fauna is small, comprised of only two genera and five species that are distributed in Mexico, the United States, and southeastern Canada (Figs. 1-9): Dasyvalgus mexicanus (Cazier), Valgus californicus Horn, V. canaliculatus (Olivier), V. hemipterus Linnaeus, and V. seticollis (Palisot de Beauvois). The Old World species V. hemipterus is adventive in the New World.

Valgine scarabs possess numerous behaviors and traits that attract investigation. Valgines are among the few scarabs that possess dorsal and ventral scale-like setae, a trait shared with the monkey beetles (Scarabaeidae: Melolonthinae: Hopliini). Some valgine species possess beautifully colored setae and bizarre setal tufts. According to Crowson (1981), setae may play a part in creating a cryptic or adaptive color pattern in beetles. Some female valgine beetles possess an ex-

\footnotetext{
${ }^{1}$ Division of Entomology, University of Nebraska State Museum, W436 Nebraska Hall, University of Nebraska, Lincoln, NE 685880514 .

${ }^{2}$ Utah State University, Logan, UT 84321.
}

ternal ovipositor at the apex of the pygidium (herein referred to as a pygidial spine [Figs. 19-24]). This character is unique within the Scarabaeoidea. Elongate ovipositors, such as those in the Valgini, are characteristic of beetles whose larvae live in dead wood (e.g., Cerambycidae, Cupedidae, Oedimeridae) (Crowson 1981). Ricchiardi (2000) noted that the pygidial spine in valgine scarabs is not used to deposit eggs deep into substrate. Rather, he postulated that the pygidial spine is used to manipulate the substrate where the egg will be laid.

Most adult valgine scarabs are nectivorous and are associated with many kinds of shrubs and flowering trees (Krikken 1978), and some species are associated with termites (Isoptera) (Linsley and Michener 1943, Ritcher 1958, Evans 1986). In the New World, species of Valgus are associated with two genera of termites: Reticulitermes (Rhinotermitidae) and Zootermopsis (Termopsidae). Valgus seticollis and V. canaliculatus are associated with species of Reticulitermes; V. californicus is associated with species of Zootermopsis. The nature of the association between valgines and termites is not known. Valgines may be obligate termitophiles that coevolved with their hosts, or they may simply use termite colonies to take advantage of a stable environment and for access to a larval food source. Coevolutionary phylogenetic analyses of termites and valgine scarabs are necessary to address these interesting questions.

Monophyly of the Valgini is well established based on the widely separated hind coxae that are autapomorphous (Krikken 1984) and several apomorphic hindwing characters (Browne and Scholtz 1998). The tribe is a member of the scarab subfamily Cetoniinae which includes 12 tribes (Krikken 1984), including the tribes Cetoniini and Trichiini. Classification of the group, either as a subfamily or tribe, has varied. The valgine scarabs were considered to be a subfamily 


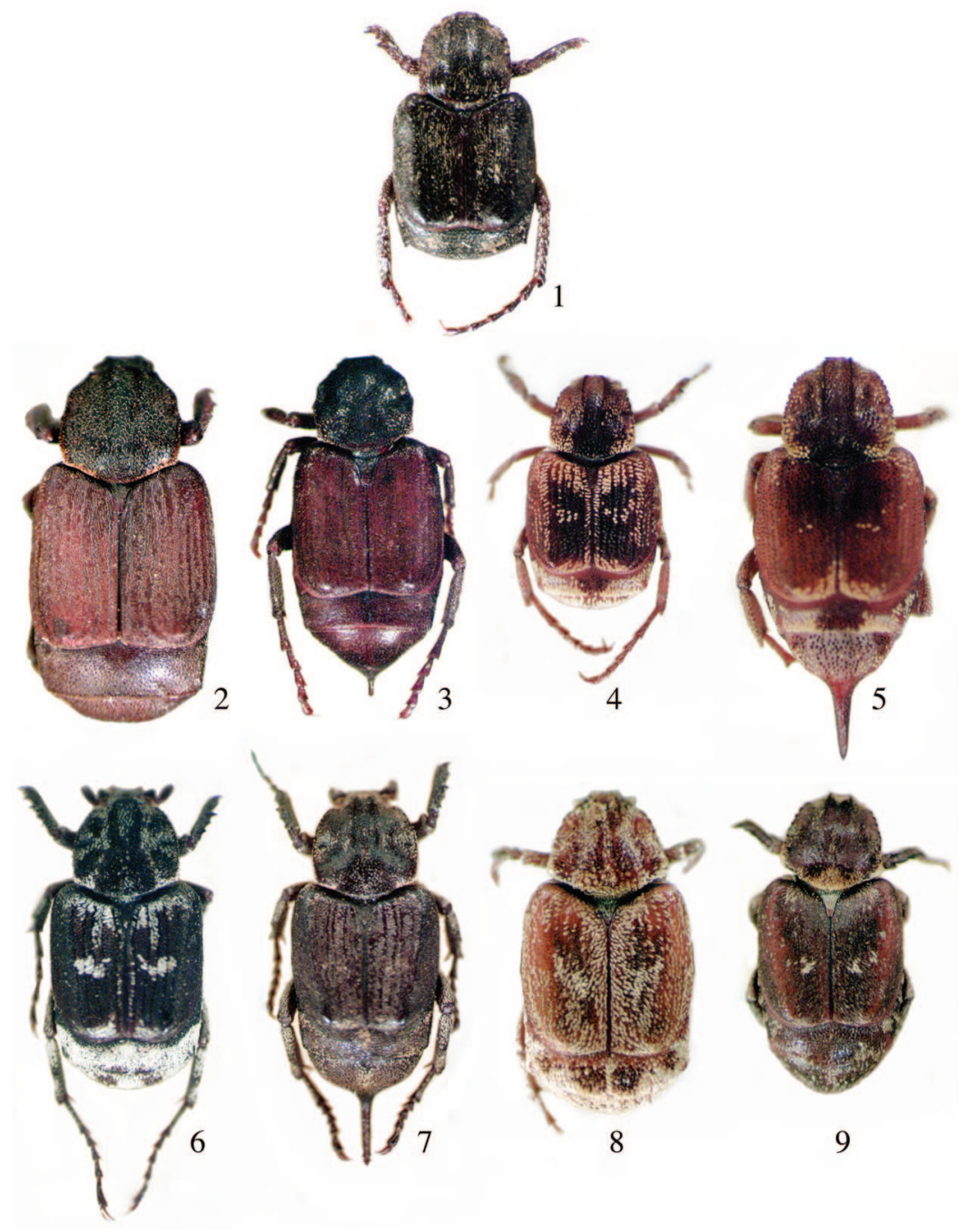

Figs. 1-9. New World valgine scarabs, left to right. 1) D. mexicanus, male; 2-3) V. californicus, male and female (respectively); 4-5) V. canaliculatus, male and female (respectively); 6-7) V. hemipterus, male and female (respectively); 8-9) V. seticollis, male and female (respectively).

within the Scarabaeidae, composed of the tribes Valgini and Microvalgini (Schenkling 1921, Krikken 1978, Ratcliffe 1991). However, recent work considered the group to be a tribe that is composed of the subtribes Valgina and Microvalgina (Krajcik 1999, Ratcliffe 2002). The Microvalgina includes 67 species in three genera found in the African, Australian, and Indomalaysian regions (Krajcik 1999). The Valgina includes $\approx 265$ species in 32 genera found in all major biogeographic regions except the Australian region (Krajcik 1999, Antoine 2002). Based on the Afro-Australian distribution of the subtribe Microvalgina, Krikken (1984) hypothesized that the tribe Valgini is an ancient group that possibly dates to the Cretaceous (65140 Mya).

Members of the Valgini have had a history of taxonomic strife due, in part, to character differences between males and females and due to the great amount of intraspecific variation in the distribution and color of scales. Distribution of setae, color of setae, and setal patches all vary greatly within a species. Furthermore, setae are commonly abraded from specimens or discolored due to a build-up of fat. Thus, these characters are not entirely reliable for identification of species. In addition to variation in coloration and distribution of setae, males and females of the same species often share little resemblance. Females of some species possess a pygidial spine (lacking in males), may have stouter legs and tarsi (more gracile in males), may have stiff setae on the abdomen (scales in males), and may have poorly developed setal tufts on the apex of the pygidium and propygidium (well developed in males). Difficulty associating males with females led to the description of different species for the same taxon as well as multiple generic placements for a single taxon. 

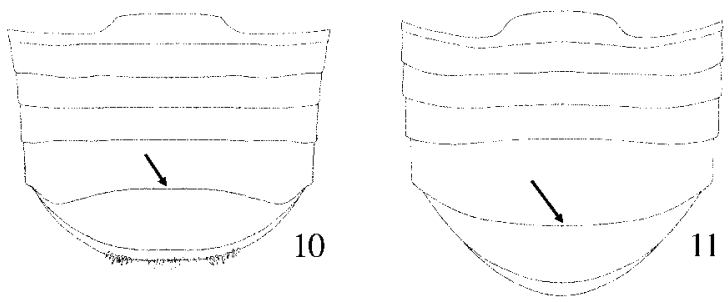

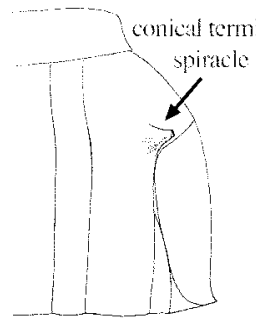

12

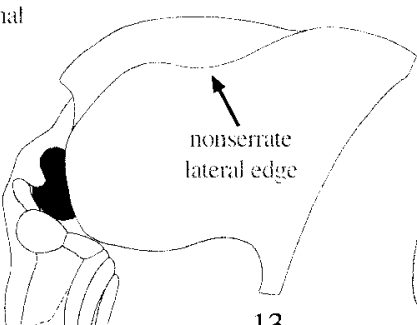

13

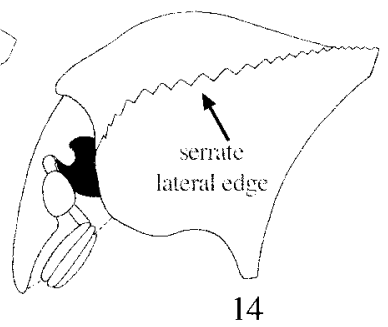

14
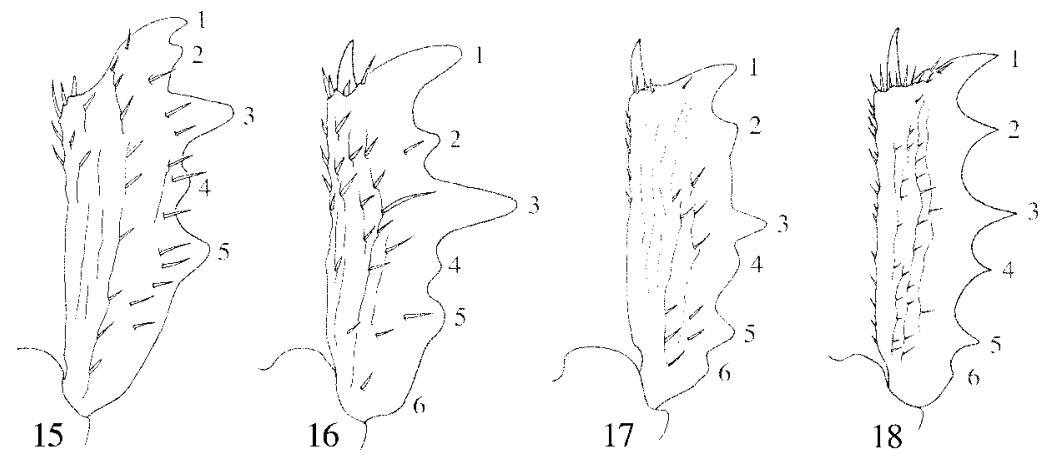

Figs. 10-18. 10-11) Ventral view of sternites in V. seticollis, male (10) and female (11) showing differences between the sexes. 12) Lateral view of abdomen of $D$. mexicanus showing conical terminal spiracle. 13-14) Lateral view of head and pronotum in $V$. californicus and V. canaliculatus (respectively) showing nonserrate (13) or serrate (14) pronotal margin. 15-18) Male foretibia (dorsal view) showing form and external teeth in D. mexicanus (15), D. sellatus (16), V. canaliculatus (17), and V. hemipterus (18).

We also observed variation in form of the male genitalia. The value of male genitalia in taxonomy and identification of species has long been recognized (Sharp and Muir 1912, d'Hotman and Scholtz 1990), and there is little variation within most species of scarab beetles (Endrödi 1985). However, one species of New World valgine, V. seticollis, has extremely variable male genitalia although there is an overall similarity in pattern (Figs. 31-35). Other characters that we examined are consistent within this species, including form of the tarsomeres, pygidial spine, pronotum, sternites, and spiracles. Lacking other morphological characters to separate the genitalic forms, we conservatively group all the forms as one species. A thorough study of the genitalic forms of $V$. seticollis would be an excellent topic for a molecular analysis and could reveal interesting evolutionary patterns.

Valgine scarabs are in need of a comprehensive taxonomic revision and phylogenetic analysis. Relationships among the genera of the subtribe Valgina have not been addressed. Phylogenetic analyses and morphological studies of world taxa would help to determine the relationship between genera and spe- cies, create predictive classifications, and aid in the study of evolution and adaptation in the group. We provide a foundation for identification of New World Valgini and for future phylogenetic, ecological, and systematics studies on this interesting group of scarab beetles.

\section{Contributions to New World Valgine Beetles}

The biology of V. canaliculatus drew the interest of two prominent entomologists, Lee Townsend and Paul Ritcher. These entomologists intended to publish a synopsis of the valgine scarabs of North America. They amassed loans and literature for a work that never quite reached fruition. The materials that Townsend and Ritcher accumulated added greatly to our research. Townsend's handwritten notes and drawings helped to corroborate our hypotheses regarding taxonomic status of genera and species and posed alternative hypotheses that caused us to probe more deeply into some of the problems associated with the taxonomy, species concepts, and variation of the group. Materials from Townsend and Ritcher in- 
cluded loans of specimens from many United States collections, translations of literature, distribution maps, and notes on problematic names and concepts. Also included was correspondence with prominent entomologists of the past: Gilbert J. Arrow (British Museum of Natural History, London), Edward A. Chapin (Smithsonian Institution, Washington, DC), and Herbert $\mathrm{H}$. Ross (Natural History Survey, Urbana, IL). These materials are now archived at the University of Nebraska State Museum, Division of Entomology.

Townsend and Ritcher's interests in valgine scarabs began serendipitously. In the summer of 1944, Townsend (then Associate Professor of Entomology, University of Kentucky, Lexington, KY) and Ritcher (then Assistant Entomologist, Kentucky Agriculture Experiment Station) reared two unidentified larvae: "13 July 1944: Ritcher collected two larvae (third stage) from soil beneath dead log near Sacred Circle on North Elkhorn Creek. These were placed in a tin salve box for rearing. On 27 July 1944 a Valgus canaliculatus male was found in the box. The finding of these larvae was the stimulus which prompted more collecting" (from Townsend's handwritten notes). Townsend and Ritcher observed and reared V. canaliculatus for two summer seasons (1944-1945). Townsend's notes provide details on the daily and weekly development of larvae, dimensions of pupal cells, number of larvae in termite galleries (as many as 112 ), the bluish color of larvae, oviposition, mating (males lie on their back while mating due to the female's pygidial spine), and many other details. Townsend also noted that only males feed, and females could not be induced to feed.

As a result of these collaborative endeavors, Ritcher (1966) published some biological and larval data, and Townsend began a manuscript on the biology and taxonomy of Valgus species. Townsend borrowed specimens, gathered literature, and inquired about the location of type specimens while his students were away during World War II. After his students returned from the war, Townsend was again occupied with teaching, and he had little time to devote to the Valgus project. Townsend retired in June 1973. He transferred correspondence, specimens, loan forms, notes, and literature to Ritcher and asked that Ritcher finish the manuscript (personal communication Townsend to Ritcher, 29 May 1973). Ritcher, who was then curator of the insect collection at Oregon State University (Corvallis, OR), agreed but did not complete the project before his retirement in 1974. Although he lived until 1991 and the age of 81 , he no longer conducted research after his retirement. Thus, upon retirement, Ritcher passed the Valgus project and all its materials to Dave Carlson. Carlson completed his M.S. and Ph.D. with Ritcher (1973 and 1976, respectively). He contributed to the Valgus project by studying the structure of the male genitalia and internal sac of Valgus species and also by collecting V. californicus in California and Oregon. Carlson (now in Fair Oaks, CA) continues his avocation in scarab systematics, but limited time prevented him from working on the Val- gus project. In 2002, Carlson passed the Valgus project and all its materials to us.

\section{Materials and Methods}

The results of this study are based on specimens from 28 institutions. We initiated loans during the course of this research, and we used material that was loaned to Townsend and Ritcher between 1944 and 1978. We made efforts to acknowledge the curators and personnel who loaned these specimens. Some of the original loan paperwork exists, and we have made efforts to return all specimens to the proper institutions. The collections and their acronyms are as follows: AMNH, American Museum of Natural History, New York, NY (J. G. Rozen, J. C. Pallister); BCRC, Brett C. Ratcliffe Collection, Lincoln, NE (B. C. Ratcliffe); BMNH, British Museum of Natural History, London, England (G. J. Arrow); CASC, California Academy of Sciences, San Francisco, CA (E. C. VanDyke, E. S. Ross, D. Kavanaugh, R. Brett); CDAE, California State Collection of Arthropods, Sacramento, CA (C. Bellamy, F. Andrews); CNCI, Canadian National Collection, Ottawa, ON (W. J. Brown); DCCC, Dave C. Carlson Collection, Fair Oaks, CA (D. Carlson); EMEC, University of California, Berkeley, CA (J. A. Chemsak); FMNH, Field Museum of Natural History, Chicago, IL (J. Boone, A. Newton, M. Thayer); INHS, Illinois Natural History Survey, Champaign, IL (H. H. Ross); IRCW, University of Wisconsin, Madison, WI (J. R. Baker, L. Bayer); KSEM, University of Kansas, Lawrence, KS (H. B. Hungerford, B. Beatty); LAGO, Paul Lago Collection, University, MS (P. Lago); LSAM Louisiana State University, Baton Rouge, LA (J. B. Chapin, C. Carlton); MCZC, Museum of Comparative Zoology, Harvard University, Cambridge, MA (E. O. Wilson); MEMU, Mississippi Entomological Collection, Mississippi State University, MS State, MS (T. Schiefer); MLUH, Martin-LutherUniversität, Wissenschaftsbereich Zoologie, Halle, Germany (K. Schneider); MSUC, Michigan State University, East Lansing, MI (R. L. Fischer); PURC Purdue University, West Lafayette, IN (J. J. Davis); UCDC, University of California, Davis, CA (L. Kimsey); UGCA University of Georgia, Athens, GA (W. T. Atyeo, H. H. Ross); UMMZ, University of Michigan, Ann Arbor, MI (C. Mickel); UNSM, University of Nebraska State Museum, Lincoln, NE (B. C Ratcliffe, M. L. Jameson); USNM, United States National Museum, Washington, DC (E. A. Chapin, O. L. Cartwright, P. Spangler) (collection currently at University of Nebraska State Museum; B. C. Ratcliffe, M. L. Jameson); RHTC, Robert H. Turnbow Collection, Fort Rucker, AL (R. H. Turnbow); SSCC, S. Summerland Collection, Vincennes, IN (S. Summerland); OSUC, The Ohio State University, Columbus, $\mathrm{OH}$ (J. N. Knull); and ZMUC, Zoological Museum, University of Copenhagen, Denmark (O. Martin).

We observed a great amount of intraspecific variation in the form, color, and distribution of setae. Based on this variation, we do not rely solely on these characters (see discussion in Introduction). Body mea- 

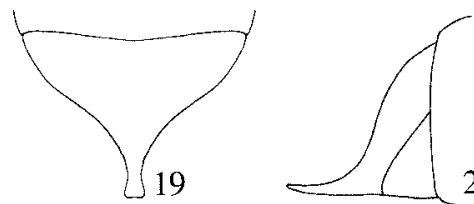

Valgus californicus

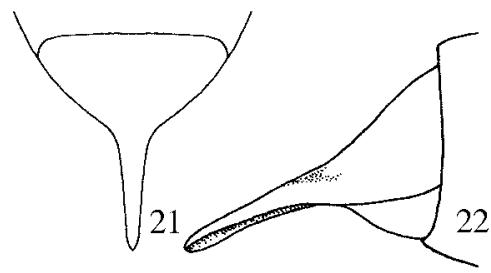

Valgus canaliculatus

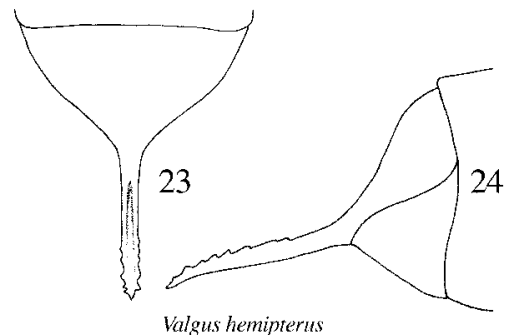

Valgus hemipteras

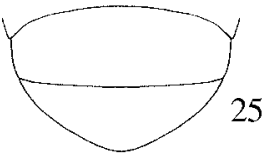

Valgus seticollis

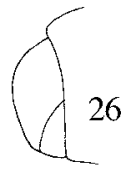

Figs. 19-26. Dorsal and lateral views (respectively) of female pygidium and pygidial spines in; 19-20) V. californicus, 21-22) V. canaliculatus, 23-24) V. hemipterus, and 25-26) V. seticollis.

surements and key characters are based on the following standards. Body length was measured from the apex of the pronotum to the apex of the pygidium. Lateral edges of the pronotum possessed obvious serrations (Fig. 14) or were lacking obvious serrations (Fig. 13). Terminal spiracles are described as distinctly produced and conical ("cone" produced more than two spiracle diameters; Fig. 12), weakly convex (produced less than one spiracle diameter), or flat. Female pygidial spine is described as it looks when viewed dorsally (Figs. 19 and 21, 23) or laterally (Figs. 20 and $22,24)$. In descriptions and key couplets, elytral cuticular color is viewed using magnification and illumination. Elytral cuticular color describes the color of the cuticle rather than color of the setae and scales.

Locality data are included for each species. We record the country and state/province (Mexico and Canada) or state and county (United States) from which specimens were examined.

The phylogenetic species concept (Wheeler and Platnick 2000) was applied in this work: "A species is the smallest aggregation of (sexual) populations or (asexual) lineages diagnosable by a unique combination of character states."

The International Commission of Zoological Nomenclature (ICZN) requires that neotype designation is valid only when there is "exceptional need," and only when the need is "expressly stated" (Article 75.3; ICZN 1999). We designate neotype specimens for two species to preserve the stability of nomenclature by selecting one specimen as the name-bearing type because the original type specimens have been lost or destroyed. The neotype specimen ties the published name to an actual specimen and serves as a reference for the taxon. We designate a neotype for Valgus serricollis Fitch and Cetonia canaliculata Olivier to avoid taxonomic confusion of species and names for these taxa.

The following characters serve to separate male and female specimens. Males: Pygidial spine absent, apex of pygidium in ventral view with fringe of setae and/or border of penultimate sternite anteriorly sinuate at middle (Fig. 10). Females: Pygidial spine present (Figs. 19-24) or, if lacking (Figs. 25-26; V. seticollis), then apex of pygidium in ventral view without fringe of setae and/or border of penultimate sternite posteriorly sinuate at middle (Fig. 11).

\section{Key to Genera and Species of New World Valgini}

1. Terminal spiracles conical, distinctly produced (Fig. 12). Posterior tarsomeres subequal in length . . . . . . Dasyvalgus mexicanus (Cazier)

$1^{\prime}$. Terminal spiracles not distinctly produced. Posterior tarsus with first tarsomere as long as or longer than tarsomeres two and three combined .................... . .

$2\left(1^{\prime}\right)$. Lateral edges of pronotum not serrate (Fig. 13; setae may need to be removed to view edge of pronotum). Female with short, scoop-like pygidial spine (Fig. 19); spine moderately recurved in lateral view (Fig. 20). Valgus californicus Horn

2'. Lateral edges of pronotum serrate (Fig. 14; setae may need to be removed to view edge of pronotum). Female without pygidial spine (Fig. 25) or, if present, female with acuminate pygidial spine (Figs. 21 and 23); spine moderately decurved in lateral view (Figs. 22 and 24) . . . . . . . 3

$3\left(2^{\prime}\right)$. Body length (as measured from apex of pronotum to apex of pygidium) $4.0-6.0 \mathrm{~mm}$. Female without pygidial spine (Figs. 25-26) or pygidial spine of female without lateral serrations (Figs. 21-22). Elytral cuticular color reddish brown, brown, or castaneous . . . . . . . . . 4

$3^{\prime}$. Body length (as measured from apex of pronotum to apex of pygidium) $8.0-9.0 \mathrm{~mm}$. Pygidial spine of female with irregular, lateral serrations (Figs. 23-24). Elytral cuticular color piceous . . . . . . . . . . . . . . Valgus hemipterus (L.)

4(3). Male with dense patch of overlapping yellow and cream-colored setae on ventral surface of abdomen. Female with acuminate pygidial spine (Fig. 21); spine decurved in lateral view (Fig. 

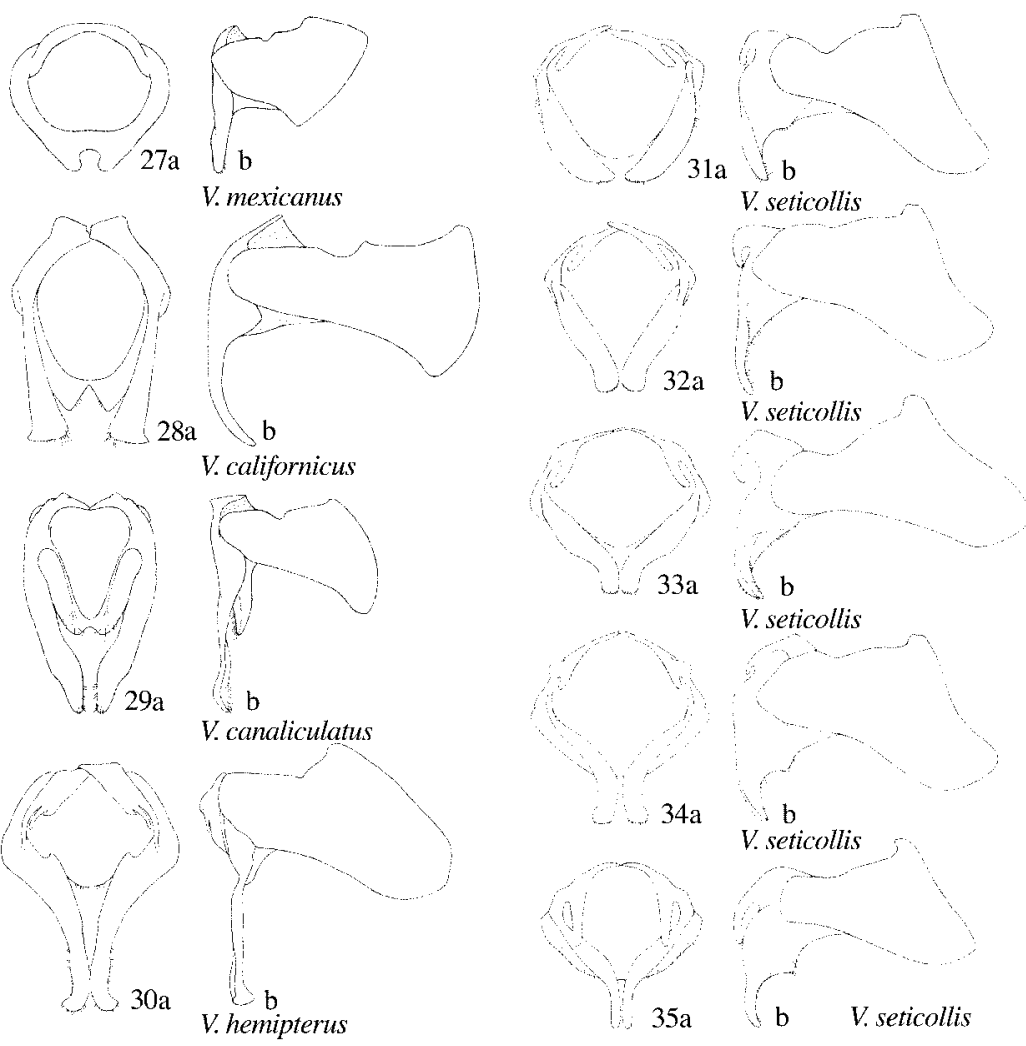

Figs. 27-35. Dorsal view (a) and lateral view (b) of male genitalia in; 27) D. mexicanus, 28) V. californicus, 29) V. canaliculatus, 30) V. hemipterus, and 31-35) V. seticollis.

22). Elytral cuticular color reddish brown or brown ........ Valgus canaliculatus (Olivier)

$4^{\prime}$. Male with moderately dense, tawny setae on ventral surface of abdomen, setae not overlapping and dense. Female without acuminate pygidial spine (Figs. 25-26). Elytral cuticular color of male reddish brown; cuticular color of female castaneous ..... . Valgus seticollis (Palisot de Beauvois)

\section{Genus Dasyvalgus Kolbe, 1904}

(Figs. 1; 12; 15; 27a, b; 36)

Dasyvalgus Kolbe, 1904: 25, 34 (valid name). Type species: V. sellatus Kraatz 1883 (designated by Arrow 1944).

Anepsiovalgus Kolbe, 1904: 24, 30 (junior synonym). Nannovalgus Kolbe, 1904: 24, 26 (junior synonym). Plocovalgus Kolbe, 1904: 45 (junior synonym).

Syngonovalgus Kolbe, 1904: 24, 28 (junior synonym). Trichovalgus Kolbe, 1904: 36, 44 (junior synonym).

Nipponovalgus Sawada, 1941: 1-14 (junior synonym).

Diagnosis (Fig. 1). The genus Dasyvalgus is characterized by the following morphological characters (based on Arrow 1944): propygidial spiracles distinctly produced and conical (Fig. 12) (simple in Valgus); sternite 6 of abdomen retractile and smooth (with scales and not retractile in Hybovalgus Kolbe; retractile and smooth in Valgus); propygidial spiracles placed one to two spiracle diameters from basal border of pygidium (four to five spiracle diameters from basal border of pygidium in Valgus); foretibia with five external teeth (Figs. 15-16) (five to six teeth in Valgus [Figs. 17-18]); second elytral interval wider at elytral base than at elytral apex (elytral interval parallel in Valgus); elytral striae sinuous (straight in Mimovalgus Arrow; sinuous in Valgus); middle coxae separated by less than width of adjacent femora (more widely separated in Chromovalgus Kolbe; separated by less than width of adjacent femora in Valgus).

Distribution (Fig. 36). The genus Dasyvalgus contains 109 species found in the Palaearctic and Indomalaysian regions (Krajcik 1999). One species is found in the New World in southern Mexico.

Biology. Nothing is known of the natural history of the species in the New World. Females of most Dasyvalgus species are rare or unknown (Ricchiardi 1996).

Discussion. Species of Dasyvalgus are readily recognizable due to the conical form of the spiracles on the propygidium (Fig. 12). One species, V. mexicanus, possesses the character states that are consistent with characters shared with other species in the genus Dasyvalgus. We compared the New World species with $D$. sellatus, the type species of the genus. After careful analysis, we transfer $V$. mexicanus to the genus 


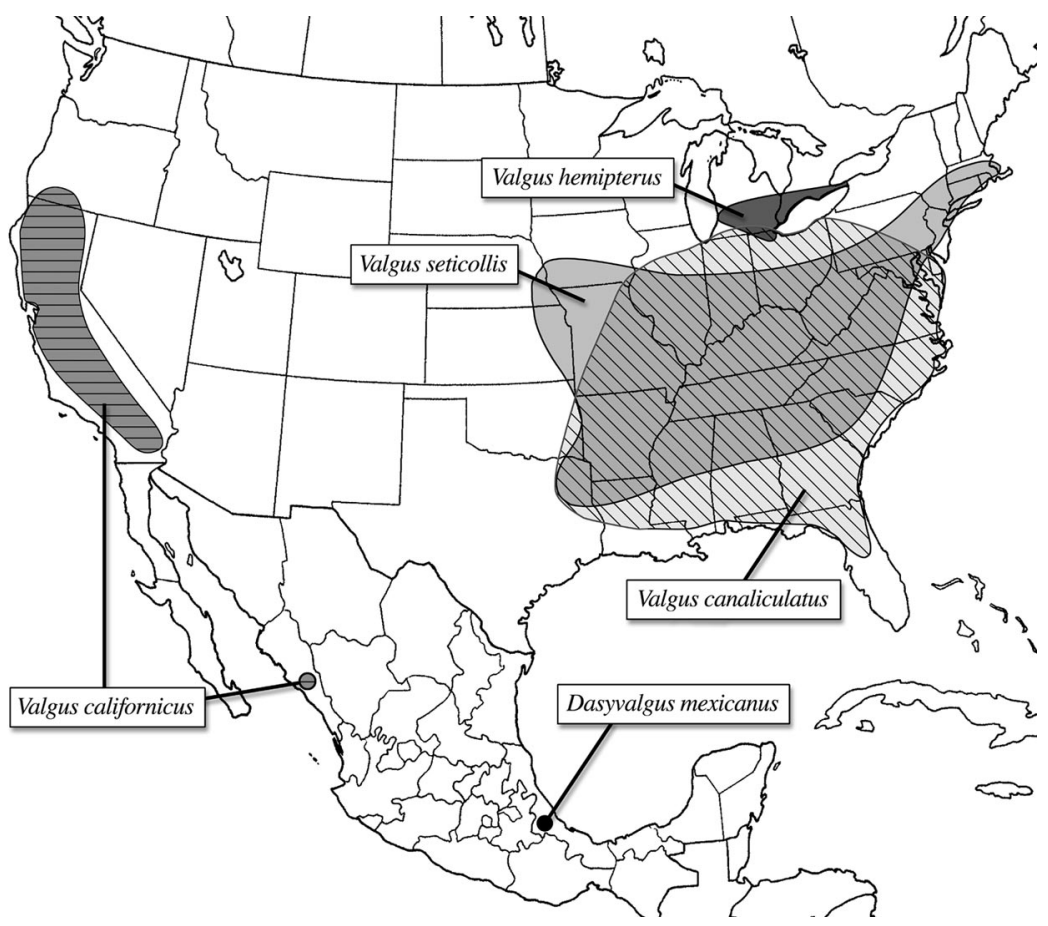

Fig. 36. Distribution of valgine scarabs in the New World.

Dasyvalgus based on the above characters. Arrow also believed that V. mexicanus seemed to be more appropriately placed in the genus Dasyvalgus (personal communication, Arrow to Townsend, 17 March 1947). Thus, one species of Dasyvalgus is found in the New World in southern Mexico.

\section{Dasyvalgus mexicanus (Cazier, 1937)} New Combination

(Figs. 1; 12; 15; 27a, b; 36)

Dasyvalgus mexicanus (Cazier, 1937: 190-191) (valid name).

Valgus mexicanus Cazier, 1937: 190-191 (original combination).

Diagnosis (Fig. 1). Length 4.0-5.0 mm. Dorsal surface with sparse, castaneous setae. Ventral surface of abdominal sternites with sparse, tawny setae. Setae of elytra more or less parallel sided. Elytral cuticular color castaneous. Pronotum serrate on lateral edge; longitudinal medial ridge poorly developed; short carina present between longitudinal medial ridge and lateral edge of disc; basolateral angle square or weakly acute. Terminal spiracle distinctly produced and conical (Fig. 12). Posterior tarsomeres subequal in length. Male genitalia as in Fig. 27a, b. Female unknown.

Distribution (Fig. 36). The species is known only from Mt. Orizaba, suggesting a relictual distribution (Morón et al. 1997). Morón et al. (1997) stated that this species is found in montane forest, possibly between 1,500 - 1,600-m elevation.
Locality Records. MEXICO: VERACRUZ: Mt. Orizaba.

Phenology. June.

Biology. Larvae are not described. Natural history is unknown

Discussion. Cazier (1937) described D. mexicanus based on seven specimens, all of which were collected in Orizaba, Mexico, by G. Trussel. During the course of this research, we examined four specimens from the type series. In his description, Cazier (1937) noted characters of the tarsi, thorax, and pygidium that differed from other New World Valgini, but he did not note the conical form of the pygidial spiracles. Female specimens of $D$. mexicanus are not known, but based on other species of Dasyvalgus, we hypothesize that the female will possess a pygidial spine.

\section{Genus Valgus Scriba, 1790}

(Figs. 2-9, 10-14, 17-18, 28-36)

Valgus Scriba, 1790: 66 (valid name). Type species: Scarabaeus hemipterus Linnaeus 1758: 351 (designated by Scriba 1790).

Acanthurus Kirby, 1827: 155 (junior synonym).

Homovalgus Kolbe, 1897: 214-215 (junior synonym).

Diagnosis (Figs. 2-9). The genus Valgus is characterized by the following morphological characters (based on Arrow 1944): propygidial spiracles not produced and conical (produced and conical in Dasyvalgus [Fig. 12]); sternite 6 of abdomen retractile, smooth, shining (with scales and not retractile in $\mathrm{Hy}$ - 
bovalgus; retractile and smooth in Dasyvalgus); propygidial spiracles placed four to five spiracle diameters from basal border of pygidium (one to two spiracle diameters in Dasyvalgus); foretibia with five to six external teeth (Figs. 17-18) (foretibia with five teeth in Dasyvalgus [Figs. 15-16]); second elytral interval subequal in width at base and apex (broader at base than at apex in Dasyvalgus); elytral striae sinuous (straight in Mimovalgus; sinuous in Dasyvalgus); middle coxae separated by less than width of adjacent femora (more widely separated in Chromovalgus; separated by less than width of adjacent femora in Dasyvalgus).

Distribution (Fig. 36). The genus Valgus contains 20 species found in the Nearctic, Palaearctic, and Indomalaysian regions (Krajcik 1999). In the New World, species of Valgus are found in the United States, southeastern Canada, and Mexico.

Biology. Valgus species have a 1-yr life cycle (Ritcher 1958). Adults can be found on flowers in the spring and summer (Ratcliffe 1991, 2002). Mating has been observed in termite galleries in stumps or fallen trees (Ritcher 1958). Larvae, pupae, and adults are found in decaying wood associated with termite colonies (Ritcher 1958). Species in the genus are commonly found in colonies of Reticulitermes sp. in the eastern United States (Banks and Snyder 1920) and in association with Zootermopsis sp. (Banks and Snyder 1920, Linsley and Ross 1940, Linsley and Michener 1943, Evans 1986) in the western United States.

Females of most Valgus species possess an external ovipositor at the apex of the pygidium (Figs. 19-26; referred to here as a pygidial spine), which is used to create oviposition sites (Arrow 1944, Mahar 1989) or to manipulate the substrate in which the egg will be placed (Ricchiardi 2000). This morphological structure is unique within the Scarabaeoidea. Valgine larvae feed on the walls of termite burrows in logs or standing dead trees (Ritcher 1958). The larvae of three New World species have been described: Valgus californicus Horn (Ritcher 1966), Valgus canaliculatus (Olivier) (Ritcher 1945, 1966), and Valgus hemipterus L. (Medvedev 1969).

Discussion. The genus Homovalgus was synonymized with Valgus (Ratcliffe 1991). This genus contained only one species, H. seticollis (Palisot de Beauvois). Use of this monotypic genus was sporadic. Cazier (1937: 191) elected not to use the genus because it had "little value." Krikken (1978) used one character (the weakly protuberant form of the pronotal base) to separate Valgus and Homovalgus. However, Krikken was dubious of the usage of the genus, and he stated (Krikken 1986: 16) "whether indeed seticollis deserves a separate generic position remains to be seen." The genus was characterized based on two character states that are homoplastic within the Valgini: 1) lack of a pygidial spine in the female and 2) a weak basal pronotal protuberance. The female pygidial spine may be present or absent within valgine genera (e.g., Oreoderus; Ricchiardi 2000). Arrow (1944) noted that the pygidial spine may be present or absent between closely related species. Thus, this character is not sufficient for separating genera. We found little difference in the form of the pronotal base and believe that this character is insufficient for separation of genera. Thus, based on the lack of shared, derived characters for the genus Homovalgus, we agree with the synonymy by Ratcliffe (1991).

Fossil or subfossil remains of two Valgus species have been described. Valgus oeningensis Heer (Heer 1862) was described from Miocene deposits (14.5 Mya) in Kesselstein, Germany (Krell 2000). Subfossil remains of $V$. hemipterus (foretibia and femur) found in southern Sweden and dated between 7000 and 5000 yr BP provide evidence that this region had habitat suitable for this species (Lemdahl 1990).

Taxonomic synopses of the New World species of Valgus were provided by Casey (1915), Cazier (1937), Arrow (1944), and Krikken (1978).

Valgus californicus Horn, 1870

(Figs. 2; 3; 13; 19; 20; 28a, b; 36)

Valgus californicus Horn, 1870: 78 (valid name).

Diagnosis (Figs. 2-3). Length 8.0-9.0 mm. Dorsal surface (male and female) with sparse, dark brown setae. Ventral surface of abdominal sternites (male and female) with sparse, dark brown setae. Setae of elytra broader at apex and narrowed at base. Elytral cuticular color (male and female) castaneous. Pronotum not serrate on lateral edge (Fig. 11); longitudinal, medial ridge poorly developed; short carina absent between longitudinal medial ridge and lateral edge of disc; basolateral angle square. Terminal spiracle not distinctly produced and not conical. Posterior tarsus (male and female) with first tarsomere as long as tarsomeres 2 to 3 combined. Female pygidial spine (dorsal view) short, scoop-like, lacking lateral serrations (Fig. 17); lacking longitudinal groove (ventral view); moderately reflexed (lateral view; Fig. 18). Male genitalia as in Fig. 26a, b.

Distribution (Fig. 37). Southern Oregon, California, and Sinaloa state in Mexico. The range of $V$. californicus includes the southern Cascades, Sierra Nevadas, San Jacintos Mountains, and the Coast Range (Santa Cruz) Mountains in California (Ritcher 1966). A 700-mile disjunction separates specimens recorded from southern California and one specimen (deposited at CASC) from Sinaloa, Mexico (Culiacán) and brings into question the validity of the collecting data on this specimen. It is possible that this disjunction is due to incorrect collecting data or lack of collecting between southern California and Sinaloa. The specimen from Sinaloa represents a new Mexican distributional record.

Locality Records. USA. CALIFORNIA: Alpine, Calaveras, El Dorado, Fresno, Lassen, Merced, Placer, Riverside, Santa Cruz, Siskiyou, Trinity, Tulare, Tuolumne. OREGON: Jackson, Klamath. MEXICO: SINALOA: Culiacán.

Phenology. May and June.

Biology. V. californicus is an inquiline in the nests of the large termites, Z. angusticollis Hagen (Banks and 
Snyder 1920) and Z. nevadensis (Hagen) (Linsley and Michener 1943). Nests occur beneath the loose bark of trees and stumps or in damp, rotting wood at the base of trees. Pupae and larvae of V. californicus were found in small hollows or cells made from termite castings (Hinton 1930). Adults were collected in ponderosa pine (Pinus ponderosa Laws) (Linsley and Ross 1940) and fire-killed sugar pine (Pinus lambertiana Dougl.) (Hinton 1930) at elevations from 1,372 to $2,743 \mathrm{~m}$.

Evans (1986) observed V. californicus in an area of forest that had been logged leaving a number of 0.60 0.91-m-tall stumps of ponderosa pine. These stumps were occupied by Zootermopsis sp. and V. californicus. Evans observed males, females, and copulating pairs in blind galleries in the dry upper portion of the stumps. Third stage larvae were also observed in loose cells constructed of termite castings. The third-stage larva was described by Ritcher (1966).

\section{Valgus canaliculatus (Olivier, 1789)}

(Figs. $4 ; 5 ; 14 ; 21 ; 22,29 \mathrm{a}, \mathrm{b} ; 36$ )

Valgus canaliculatus (Olivier, 1789: 69) (valid name). Neotype male at UNSM labeled: a) "Virginia: Montgomery County; Blacksburg $37 \mathrm{~N}$; $80 \mathrm{~W}$; 14 June 1997 Sweeping Vegetation S. W. Lingafelter, Coll." (typeface), b) "Valgus canaliculatus (Olivier) det. K. A. Swoboda 2002" (typeface), c) "Cetonia canaliculata Olivier 1789: 69, Neotype det. M. E. Jameson 2004" (handwritten and typeface, red label). Neotype here designated. The location of the holotype is unknown. We searched the Olivier collection in the Museum National d'Histoire Naturelle, Paris, but we were unable to locate the type specimen. Because Fabricius apparently used the same specimen as Olivier for his description (that of Lee), we examined two specimens of $V$. canaliculatus from Fabricius' collection at ZMUC. Specimens were in bad condition (they could not be identified with certainty as V. canaliculatus) and lacked label data that might have indicated they were from the Lee collection. Thus, we selected a specimen from Virginia (representing "America boreali") to serve as the neotype.

Cetonia canaliculata Olivier, 1789: 69 (original combination).

Trichius variegatus Palisot de Beauvois, 1807: 59 (junior synonym).

Valgus serricollis Fitch, 1858: 697 (junior synonym). Neotype male at UNSM labeled: a) "Miss, Hinds Co., 23-V-1980, Clinton, B. Stark" (handwritten and typeface), b) "Valgus serricollis Fitch 1858: 697, Neotype det. M. E. Jameson 2004" (handwritten and typeface, red label). Neotype here designated. The location of the holotype of $V$. serricollis is unknown. We searched numerous collections for the type specimen, but were not able to locate it. Ritcher and Townsend attempted to find the type of V. serricollis at the New York State Museum, the Philadelphia Academy of Sciences, the MCZC, and UNSM [where the collection was deposited according to
Horn and Kahle (1935)]. According to correspondence to Townsend, Fitch's collection was lost due to neglect (personal communication, K. F. Chamberlain, 14 August 1945). After Fitch's death, his collection and books were acquired by Foote, a Philadelphia book dealer, and then lost. We can only conclude that the type has been lost. Fitch (1858) described the species based on one specimen and the abdomen of another from the vicinity of Jackson, MS (Hinds County). We selected a neotype from Hinds County that is similar all respects to Fitch's description. New Synonym.

Valgus minutus Casey, 1909: 283 (junior synonym). New Synonym.

Diagnosis (Figs. 4-5). Length 4.0-5.0 mm. Dorsal surface (male) with dense, tawny and dark brown setae; female with moderately dense, tawny and dark brown setae. Ventral surface of abdominal sternites (male) with dense, overlapping, tawny and yellow setae; female with sparse, tawny setae. Setae of elytra tear-dropped shaped. Elytral cuticular color (male and female) reddish brown to brown. Pronotum serrate on lateral edge (Fig. 14); longitudinal medial ridge well developed; short carina present between longitudinal medial ridge and lateral edge of disc; basolateral angle rounded. Terminal spiracle not produced and not conical. Posterior tarsus (male) with first tarsomere as long as tarsomeres 2 to 3 combined; posterior tarsus (female) with first tarsomere as long as tarsomeres 2-4 combined. Female pygidial spine (dorsal view) acuminate, lacking lateral serrations (Fig. 21); longitudinal ridge present (ventral view); moderately decurved (lateral view; Fig. 22). Male genitalia as in Fig. 29a, b.

Distribution (Fig. 36). Eastern half of the United States (from Pennsylvania and northern Florida in the east to Missouri and northeastern Texas in the west). Riley and Wolfe (2003) reported V. canaliculatus from Anderson, Brazos, and Smith counties in Texas. Valgus canaliculatus is broadly sympatric with V. seticollis.

Locality Records. USA. ALABAMA: Lee, Madison, Marion, Mobile. ARKANSAS: Benton. DELAWARE: New Castle, Sussex. DISTRICT OF COLUMBIA. FLORIDA: Highlands. GEORGIA: Chattooga, Clarke, Murray, White. ILLINOIS: Franklin, Jackson, Lawrence, Mason, Massac. INDIANA: Brown, Clark, Lawrence, Morgan, Tippecanoe, Vigo. IOWA: No data. KENTUCKY: Bell, Clark, Fayette, Henderson, Lincoln, Rockcastle, Trigg, Whitley, Woodford. LOUISIANA: Natchitoches, Ouachita, St. Landry. MARYLAND: Baltimore, Montgomery, Queen Anne's, Talbot. MICHIGAN: No data. MISSOURI: St. Louis. NEW JERSEY: No data. NORTH CAROLINA: Buncombe, Chatham, Haywood, McDowell, Mitchell, Orange, Transylvania, Washington. OHIO: Ashtabula, Crawford, DE, Franklin, Hocking, Summit. OKLAHOMA: Le Flore. PENNSYLVANIA: Adams, Allegheny, Cumberland, Dauphin, Delaware, Fayette, Somerset, Washington, Westmoreland. SOUTH CAROLINA: Florence, Kershaw, Oconee, Saluda, Spartanburg, Sumter. TENNESSEE: Hamilton, Montgomery, Morgan, 
Shelby, Stewart. TEXAS: Anderson, Brazos, Hunt, Smith. VIRGINIA: Arlington, Botetourt, Clarke, Fairfax, Fauquier, Fluvanna, James City, Loudoun, Montgomery, Nelson, Page, Prince William, Rockingham. WEST VIRGINIA: Kanawha, Ritchie.

Phenology. Adult specimens have been collected from March to early August (rarely recorded in February and November).

Biology. Adults of V. canaliculatus feed on the nectar of flowers (Ritcher 1958) from beech (Fagus sp.), buckthorn (Ceanothus sp.), dogwood (Cornus sp.), hawthorn (Crataegus sp.) (Blatchley 1910), and mock orange trees (Philadelphus sp.) (Ritcher 1966). Adults were observed on honeysuckle (Viburnum sp.), meadowsweet (Spiraea spp.), goat's beard (Aruncus sp.), blackberry (Rubus sp.), oswego tea (Monarda didyma L.), oxeye daisy (Chrysanthemum leucanthemum L.), Queen Anne's lace (Daucus carota L.), wild hydrangea (Hydrangea arborescens L.), yarrow (Achillea millefolium L.), hickory (Carya sp.), oak and white oak (Quercus sp. and Quercus alba L.), southern magnolia (Magnolia grandiflora L.), and pine and loblolly pine (Pinus sp. and Pinus taeda L.).

Townsend and Ritcher extensively studied the natural history of this species from 1944 to 1945 in Kentucky (Ritcher 1958, 1966; Townsend, unpublished manuscript). They observed large numbers of larvae in decaying maple logs. Adults passed the winter in termite galleries (Ritcher 1966). Males left the galleries in April and May, flying on warm, sunny days. During the study, Townsend and Ritcher found that only males visited flowers $(n=44)$. To address whether they consumed pollen or nectar, Townsend and Ritcher used binoculars to study activity on flowers. They observed males feeding: “21 May 1945: Seven males were taken on mock orange blossoms. The adults feeding in the mock orange blossoms were observed carefully. They feed on nectar and not on pollen. By means of the long hairs which form a brush on the distal end of each maxilla, the beetles lap the nectar from the bottom of the blossom." This observation demonstrated that males feed on nectar rather than pollen or floral parts. Mating was observed in laboratory conditions. Because of the female's welldeveloped pygidial spine, males laid on their back during copulation. Females laid eggs in cracks of the termite gallery with their ovipositor. Upon emerging, larvae immediately began to feed on surrounding wood. Larvae, which are bluish in color, developed in exposed termite galleries and did not disperse from their emergence site. Pupation occurred in July and early August in small oval cells constructed of wood fragments or soil (Ritcher 1958). Pupation began around 10 July in oval cells constructed of wood fragments or dirt adhering to the wood. Cells were 9.5-11.5 $\mathrm{mm}$ in length and $3.5-5.5 \mathrm{~mm}$ in width. Adults emerged between 20 July and 25 August.

$V$. canaliculatus is common in the nests of Reticulitermes flavipes (Kollar) (Ritcher 1958) and is frequently found with V. seticollis (Ratcliffe 1991). According to Banks and Snyder (1920), both $V$. canaliculatus and V. seticollis are commonly found in association with Reticulitermes sp.

According to Ritcher (1958), logs with V. canaliculatus contain males and females in almost equal numbers. This contradicts the statement of Casey (1915) that males are more abundant than females.

Ritcher $(1945,1966)$ described the third-stage larva. According to Ritcher (1966), Boving and Craighead's (1931) illustration of $V$. canaliculatus is actually $V$. seticollis.

Discussion. Contradictions and confusion follow this species' name with regards to distribution, authorship, and synonymies. First, Olivier's (1789) description of $V$. canaliculatus stated that the species was from the Cape of Good Hope ("Cap de Bonne-Espérance," South Africa). Fabricius (1801), apparently using the same specimen as Olivier (from the collection of "Lee"), corrected Olivier's error and stated that the species was distributed in "America boreali." Some authors interpreted these as two different species. Thus, the species name $V$. canaliculatus has been attributed to both Olivier and Fabricius. Burmeister (1842), Casey (1915), Leng (1920), Dillon and Dillon (1961), and Harpootlian (2001) attributed the name to Fabricius. However, V. canaliculatus should be attributed to Olivier. It is clear in Fabricius' description (1792) that he attributed the name to Olivier, and the species was not meant to be new to science. Arrow (personal communication to Townsend, June 1945) believed that Fabricius (1801) corrected Olivier's error concerning the habitat of $V$. canaliculatus rather than describing a new species. Many old collectors had only a vague idea regarding the origin of their specimens. Lee, from whose collection the specimen came was a British botanist who received specimens from all parts of the world (personal communication, Arrow to Townsend, June 1945). According to Arrow, the figure in Olivier (1789) "leaves no doubt in my mind that the specimen was actually the North American species to which the name is applied." Herein, we designate a neotype for $V$. canaliculatus to alleviate taxonomic confusion and stabilize the nomenclature.

Several synonymies with $V$. canaliculatus have caused confusion and nomenclatural instability. Several authors, including Schaum (1849), Melsheimer (1853), Fitch (1858), and Kraatz (1883) commented that Burmeister's concept of $V$. squamiger posed historical and nomenclatural problems. Burmeister's concept of $V$. squamiger was erroneously listed in synonymy even though Burmeister (1842) clearly credited Palisot de Beauvois as the author of V. squamiger. The problem originated due to the differences in coloration between male and female V. seticollis and Burmeister's incomplete knowledge of the variation in species of Valgus. Palisot de Beauvois (1807) described the male of $V$. seticollis as a distinct species, $V$. squamiger. Burmeister and Schaum (1840) diagnosed $V$. canaliculatus, and they believed that specimens identified as $V$. seticollis and V. squamiger ( $=V$. seticollis) represented females of $V$. canaliculatus. In his treatment of the genus Valgus, Burmeister (1842) reviewed the known species of Valgus from North Amer- 
ica. However, he did not have both male and female specimens of $V$. canaliculatus and V. seticollis. He examined specimens of male $V$. canaliculatus from the collections of Gory, Knoch, and Olivier; he relied on information from Schaum that female V. canaliculatus possess a pygidial spine. For $V$. seticollis, Burmeister (1842) stated that he studied only the female. With this incomplete basis for comparison, Burmeister (1842) redescribed V. squamiger Palisot de Beauvois (giving credit to Palisot de Beauvois), but he created several problems that have been perpetuated. Schaum (1849) clarified the resulting mishap. He stated that Burmeister's concept of female V. seticollis was correct; Burmeister's concept of male V. squamiger $(=V$. seticollis) was the male of $V$. canaliculatus; Burmeister's concept of female V. squamiger ( $=V$. seticollis) was the male of V. seticollis. Fitch (1858: 696) confirmed Schaum's observations and added: "This will serve the reader some of the embarrassments which are frequently besetting ones' path in investigating this branch of nature's work."

Another synonym, Valgus serricollis was named by Fitch (1858) and was distinguished from V. seticollis and $V$. canaliculatus based on its small size $(4.25 \mathrm{~mm})$ and presence of "orange yellow" scales on the ventral surface of the abdomen. These characters are within the range of variation that is observed in V. canaliculatus and the name is here synonymized. Fitch's collection is lost or destroyed, thus we designate a neotype for $V$. serricollis to stabilize the nomenclature.

Yet another synonym, Valgus minutus, was named by Casey (1909) based on its small size (“3.9-4.2 mm”) and reddish brown setal color. We examined paratypes of $V$. minutus, and, based on character examination and comparison with $V$. canaliculatus, we believe that these species are conspecific. We synonymize (herein) V. minutus with V. canaliculatus. Ritcher also believed that $V$. minutus was conspecific with $V$. canaliculatus due to size range and type locality in Jackson, MS (personal communication, Ritcher to J. B. Chapin, 26 September 1973).

\section{Valgus hemipterus Linnaeus, 1758}

(Figs. 6; 7; 18; 23; 24, 30a, b; 36)

Valgus hemipterus Linnaeus, 1758: 351 (valid name). Valgus hemipterus rufosquamatus Dalla Torre, 1879: 115 (junior synonym).

Valgus hemipterus rubi Baguena, 1955: 293 (junior synonym).

Diagnosis (Figs. 6-7). Length 8.0-9.0 mm. Dorsal surface (male) with dense, dark brown and tawny setae; female with moderately dense, dark brown and tawny setae. Ventral surface of abdominal sternites (male and female) with moderately dense, tawny setae. Setae of elytra oval. Elytral cuticular color (male and female) piceous. Pronotum serrate on lateral edge; longitudinal medial ridge well developed; short carina absent between longitudinal medial ridge and lateral edge of disc; basolateral angle rounded. Terminal spiracle not distinctly produced and not conical.
Posterior tarsus (male and female) with first tarsomere as long as tarsomeres 2-4 combined. Female pygidial spine (dorsal view) acuminate, with irregular lateral serrations (Fig. 23), longitudinal ridge absent (ventral view); weakly decurved (lateral view; Fig. 24). Male genitalia as in Fig. 30a-b.

Distribution (Fig. 36). In the Palearctic Region, V. hemipterus is found throughout Europe, Algeria, Tunisia (Schenkling 1922), Iran, Morocco, and southern Siberia (Krikken 1986). Fossil remains of this species that date from 7000 to $5000 \mathrm{BP}$ were found in southern Sweden and indicate that this species once occupied a more northern latitude in Europe (Lemdahl 1990). Currently, this species is established within the Great Lakes region of the United States and Canada, and its range is possibly expanding.

$V$. hemipterus was first reported in the New World by Mahar and Oemke (1981) who collected specimens in Shiawassee County, Michigan, in 1980. They reported that a log of an American elm (Ulmus americana L. ) contained $>100$ adults. In 1987, Mahar (1989) reported collecting a single female north of Martin, Allegan County, Michigan (113 km west of the first record). This suggested that $V$. hemipterus was spreading at low densities over lower Michigan (Mahar 1989). O’Brien and O'Brien (1994) reported three specimens from Ann Arbor, MI (Washtenaw County) where they were collected from flowers of dame's rocket (Hesperis matronalis L.) and lilac (Syringa vulgaris L.). In the 1990s, Steve Marshall (University of Guelph, Ontario), discovered one specimen of $V$. hemipterus near Niagara Falls, Ontario (personal communication, B. D. Gill to K.A.S., November 2002). In 2001 , one specimen of $V$. hemipterus was trapped in a Lindgren funnel trap (baited with Ipslure) at the port of Toledo, $\mathrm{OH}$ (personal communication, E. Richard Hoebeke to M.L.J., October 2001). This specimen was deposited in the Cornell University Entomology Collections, Ithaca, NY. In 2002, inspectors in Sarnia, Ontario, discovered several specimens of $V$. hemipterus in firewood that was imported from Michigan (personal communication, B. D. Gill to M.L.J., November 2002). It is unclear if this species is established in Canada.

The exact year that the species entered the United States is unknown. Townsend and Ritcher discovered no specimens of $V$. hemipterus during their studies, collecting, and correspondence from 1944 to 1978 . Krikken (1986) reported a male specimen of $V$. hemipterus collected at Rowley, MA in July 1921. However, we examined no specimens of $V$.hemipterus from this region and were unable to confirm this record.

Locality Records. CANADA. ONTARIO: Lambton, Niagara. USA. MICHIGAN: Allegan, Shiawassee, Washtenaw. OHIO: Lucas.

Phenology. Nearctic adult specimens are collected in May and June. Palearctic adult specimens are collected between April and June and in October and November.

Biology. Larvae have been collected in summer, and pupae and teneral adults in the early fall, suggesting a univoltine life cycle with adults and pupae overwintering (Mahar and Oemke 1981). Larvae are not as- 
sociated with termites (Mahar and Oemke 1981). Fallou (1889) remarked on the similarity of larval galleries made by $V$. hemipterus to those formed by termites.

Adult females were attracted to moist, rotting wood to oviposit (Mahar and Oemke 1981), although oviposition has been observed in fairly dry wood and in living trees with the bark removed (Fallou 1889). Females leave occupied wood to seek out new oviposition sites in early summer (Mahar 1989) and use their pygidial spines to create such sites. Mahar and Oemke (1981) observed a female for 15 min that used her pygidial spine, held perpendicular to her body, to gouge a hole in rotten elm wood to create an oviposition site.

According to Mahar and Oemke (1981), the entire life cycle of $V$. hemipterus can be completed within a log. Nearctic specimens were collected from rotting wood of the American elm (Ulmus americana L.). Common host trees in France are oak (Quercus sp.), birch (Betula sp.), elm (Ulmus sp.), and chestnut (Castanea sp.) (Fallou 1889). Paulian and Baraud (1982) stated that males are found on the flowers of Sorbus sp. and Spirea sp. (both Rosaceae). Medvedev (1969) found larvae in large numbers on stumps of rotting apple (Malus sp.) in Lyubotina, Khar'kov Province, Russia. Medvedev (1969) described the third-stage larvae.

Discussion. Baguena (1955) described a variety, $V$. hemipterus variety rubi, from Cercedilla, Madrid, Spain based on two males and one female. He differentiated the variety based on an "intensely" red color of the elytra, legs, and sternites. Based on Article 45.6.4 of the International Code of Nomenclature (1999), varietal names that are published before 1961 should be treated as subspecies. Krajcik (1999) incorrectly treated the name as a species.

\section{Valgus seticollis (Palisot de Beauvois, 1807) \\ (Figs. 8-11, 25, 26, 31-36)}

Valgus seticollis (Palisot de Beauvois, 1807: 59) (valid name).

Trichius seticollis Palisot de Beauvois, 1807: 59 (original combination).

Trichius squamiger Palisot de Beauvois, 1807: 60 (junior synonym).

Diagnosis (Figs. 8-9). Length 5.0-6.0 mm. Dorsal surface (male) with tawny (dense) and dark brown (sparse) setae; female dark brown (dense) and tawny (sparse) setae. Ventral surface (male) of abdominal sternites (male and female) with moderately dense, tawny setae (setae of male not overlapping). Setae of elytra oval. Elytral cuticular color (male) reddish brown; female castaneous. Pronotum serrate on lateral edge; longitudinal medial ridge well developed; short carina present between longitudinal medial ridge and lateral edge of disc; basolateral angle rounded. Terminal spiracle not distinctly produced and not conical. Posterior tarsus (male) with first tarsomere as long as tarsomeres 2-3 combined; posterior tarsus (female) as long as tarsomeres $2-4$ combined. Female pygidial spine lacking (Figs. 25-26). Male genitalia as in Figs. 31-35.

Distribution (Fig. 36). Eastern half of the United States (from Massachusetts and northern Georgia in the east to southeast Nebraska and northeast Texas in the west). Riley and Wolfe (2003) reported this species from Sabine county, TX. Valgus seticollis is broadly sympatric with $V$. canaliculatus.

Locality Records. USA. ARKANSAS: Washington. CONNECTICUT: No data. DISTRICT OF COLUMBIA. GEORGIA: Lamar, Paulding. ILLINOIS: Bond, Clark, Effingham, Schuyler, Vermillion, Williamson. INDIANA: Delaware, Orange, Tippecanoe, Vigo. KANSAS: Douglas, Shawnee. KENTUCKY: Fayette, Jefferson, Leslie, McCracken, Rockcastle, Union. MARYLAND: Anne Arundel, Baltimore, Charles, Montgomery, Prince George's. MASSACHUSETTS: Essex, Middlesex. MISSISSIPPI: No data. MISSOURI: St. Charles, St. Louis. NEBRASKA: Cass, Nemaha. NEW JERSEY: Bergen, Burlington, Camden, Gloucester, Monmouth, Passaic. NEW YORK: Orange, Putnam, Westchester. NORTH CAROLINA: Burke, McDowell, Moore, Wake. OHIO: Franklin, Madison. PENNSYLVANIA: Allegheny, Dauphin, Snyder. RHODE ISLAND: No data. SOUTH CAROLINA: Florence, Oconee, Pickins. TENNESSEE: Davidson, Morgan. TEXAS: Sabine, Smith. VIRGINIA: Fairfax. WEST VIRGINIA: Kanawha.

Phenology. Adults are collected from March to July and in October and November.

Biology. The life history of V. seticollis is probably similar to V. canaliculatus (Ratcliffe 1991). Adults and larvae are found in wood colonized with termites, such as Reticulitermes flavipes (Kollar) (Ritcher 1958, 1966). Specimens have been collected from logs or flowers of oak (Quercus sp.), pitch pine (Pinus rigida Mill.), American chestnut (Castanea dentata [Marsh.] Borkh.), and yellow-poplar (Liriodendron tulipifera L.), and from strawberry (Fragaria sp.). According to Ritcher (1958), logs usually contain a majority of females. This contradicts the statement of Casey (1915) that males and females are almost equal in numbers.

Ritcher $(1945,1966)$ described the third-stage larva. Boving and Craighead (1931) illustrate V. seticollis (incorrectly identified as V. canaliculatus).

Discussion. The nomenclatural history of $V$. seticollis has been fraught with confusion primarily due to the differences in color between males and females. As stated by Fitch (1858: 695): "The sexes of this insect differing so much in their colors, has caused great perplexity to authors and has led to much confusion in the few notices of it which have been published." The nomenclatural confusion has been embroiled with the history of V. canaliculatus (see "Discussion" under V. canaliculatus).

The unavailable name "Trichius dispar Harris" occurs in the literature (Gory and Percheron 1833, Burmeister and Schaum 1840, Burmeister 1842). Harris (1833) listed the name in "A catalog of the animals and plants in Massachusetts," but the species was never validly described. 
The invalid name "V. squamiger" occurs in the literature and throughout collections. The species name is attributed to Palisot de Beauvois (1807) and Burmeister (1842). The correct author of the name is Palisot de Beauvois. Burmeister and Schaum (1840) synonymized Trichius seticollis Palisot de Beauvois and T. squamiger Palisot de Beauvois under V. canaliculatus, believing both to be female varieties of $V$. canaliculatus (see "Discussion" under V. canaliculatus). However, in the "Handbuch der Entomologie," Burmeister (1842) treated V. seticollis, V. squamiger, and $V$. canaliculatus all as separate species. He did not make reference to his publication with Schaum (Burmeister and Schaum 1840). Schaum (1849), in an attempt to clarify the nomenclature, made the problem even more unclear. With some diligence, one can discern that Schaum believed that V. squamiger was synonymous with $V$. seticollis, and he regarded $V$. seticollis as a valid name. Fitch (1858) reiterated the history of these names and tried to clarify Schaum's views. Fitch (1858) used the name V. seticollis as the valid name. Additionally, Kolbe (1897) referred to " $V$. seticollis Beauv." and "squamiger Palis." as the same entities when he created the genus Homovalgus.

In addition to sexual differences in cuticular color (male yellowish brown, female reddish brown), we observed a great amount of intraspecific variation in the form of the male genitalia (Figs. 31-35). For example, the genitalic form in Fig. 31 occurs in Missouri (St. Louis, St. Charles), Illinois (Rushville), Ohio, and Kentucky (Buechel); the form in Fig. 32 occurs in Indiana (Muncie) and Kansas (Douglas county); the form in Fig. 33 occurs in Kentucky (Mayfield); the form in Fig. 34 occurs in Tennessee (Nashville); and the form in Fig. 35 occurs in Washington, DC. Some forms (e.g., Figs. 33-34) apparently occur within similar habitats and within proximity of one another. Characters of the pronotum, pygidial spine, and tarsomeres are consistent within all forms. Based on the lack of morphological characters to separate genitalic forms, we conservatively consider all forms to be the same species.

High intraspecific variation is noted in other taxa from this region in North America, including Nesticus spiders (Hedin 1997) and trechine carabid beetles (Barr 1985). High intraspecific variation may be indicative of biogeographic response to glaciation along the Mississippi River valley (Gates 1993). During the Wisconsin maximum ( $\approx 18,000$ yr BP), glacial-interglacial cycles triggered expansion and contraction of forest ecosystems, thus affecting dispersal, isolation, and hybridization of biotas (Gates 1993). Molecular and morphological analyses of forms of $V$. seticollis may provide valuable insights to the mechanisms of evolution, biogeography, and character plasticity.

\section{Acknowledgments}

We dedicate this work to Lee Townsend and Paul Ritcher whose materials greatly facilitated our research. We thank Dave Carlson for serving as the custodian of these materials and allowing us to make use of them. We are obliged to Paul
Lago (University, MS) for the specimen from V.canaliculatus from Hinds County, Mississippi, that was designated as the neotype of $V$. serricollis Fitch. We thank Olivier Montreuil (Museum National d'Histoire Naturelle, Paris) and Darren Mann (Oxford University Collection, Oxford) for assistance in searching for the type specimen of V.canaliculatus. We are grateful to Karla Schneider (MLUH) for sending images of Valgus species from Burmeister's collection and aiding us with the interpretation of the "Valgus problem." Members of Team Scarab at the University of Nebraska are thanked for their support and suggestions (Brett Ratcliffe, Andrew Smith, Federico Ocampo, Aura Paucar-Cabrera, Matt Paulsen, and Shauna Hawkins). The manuscript was improved by the reviewers, Matt Paulsen and Brett Ratcliffe (UNSM), and Andrew Smith (Canadian Museum of Nature). Enrico Ricchiardi (Torino, Italy) provided helpful suggestions regarding the genera Dasyvalgus, Homovalgus, and Valgus. We thank Aura Paucar-Cabrera for some illustrations in this work. This project was supported by NSF/PEET grant DEB0118669 to M.L.J. and B. C. Ratcliffe.

\section{References Cited}

Antoine, P. 2002. Révision du genre Lobovalgus Kolbe (Coleoptera, Cetoniidae, Valginae). Coléoptères 8: 191-209.

Arrow, G. J. 1944. The beetles of the lamellicorn subfamily Valginae, with a synopsis of the genera and descriptions of some new species. Trans. R. Entomol. Soc. Lond. 94: $225-246$.

Baguena, L. 1955. Scarabaeoidea nuevos o muy interesantes de la fauna Ibero-Balear y Pirenaica. Eos 31: 275-295.

Banks, N., and T. E. Snyder. 1920. A revision of the Nearctic termites. Bull. United States Nat. Hist. Mus. 108: 1-211.

Barr, T. C., Jr. 1985. Pattern and process in speciation of trechine beetles in eastern North America (Coleoptera: Carabidae: Trechinae), pp. 350-407. In G. E. Ball [ed.], Taxonomy, phylogeny, and zoogeography of beetles and ants. Dr. W. Junk Publishers, Dordrecht, The Netherlands.

Blatchley, W.S. 1910. The Coleoptera or beetles of Indiana. Bull. Indiana Dept. Geol. Nat. Resour. 1: 1-1386.

Boving, Adam, G., and F. C. Craighead. 1931. An illustrated synopsis of the principal larval forms of the order Coleoptera. Entomol. Am. N.S. 11: 1-351.

Browne, J., and C. H. Scholtz. 1998. Evolution of the scarab hindwing articulation and wing base: a contribution toward the phylogeny of the Scarabaeidae (Scarabaeoidea: Coleoptera). Syst. Entomol. 23: 307-326.

Burmeister, H., and H. Schaum. 1840. IV. Kritsche Revision der Lamellicornia melitophila. Zeit. für Entomol. 2: 353420.

Burmeister, H. 1842. Handbuch der Entomologie, Band 3, Coleoptera Lamellicornia Melitophila. Berlin, Germany.

Casey, T. L. 1909. Studies in the Caraboidea and Lamellicornia. Can. Entomol. 41: 253-284.

Casey, T. L. 1915. A review of the American species of Rutelinae, Dynastinae, and Cetoniinae. Mem. Coleoptera 6: 1-394.

Cazier, M. A. 1937. A new species of Valgus and a new generic record for Mexico. Pan-Pac. Entomol. 13: 190192.

Crowson, R. A. 1981. The biology of the Coleoptera. Academic, New York.

Dalla Torre, K. W. von. 1879. Die Käferfauna von Oberösterreich. Systematisches Verzeichnis der in Oberösterreich bisher beobachteten Käfer. Jahresbericht Vereines Naturk. Oesterreich ob. der. Ens. zu. Linz. 10: 1-125. 
d'Hotman, D., and C. H. Scholtz. 1990. Comparative morphology of the male genitalia of derived groups of Scarabaeoidea (Coleoptera). Elytron 4: 3-39.

Dillon, E. S., and L.S. Dillon. 1961. A manual of common beetles of eastern North America. Row, Peterson \& Company, Evanston, IL.

Endrödi, S. 1985. The Dynastinae of the World. Dr. W. Junk, Dordrecht, The Netherlands.

Evans, A. V. 1986. Notes on Valgus californicus Horn (Coleoptera: Scarabaeidae). Pan-Pac. Entomol. 62: 83.

Fabricius, J. C. 1792. Entomologia systematica, vol. 1. Copenhagen, Denmark.

Fabricius, J. C. 1801. Systema Eleutheratorum, vol. 1-2. Kiel, Germany.

Fallou, J. 1889. Sur les ravages causés par deux coléoptères nuisibles des environs de Paris. Rev. Sci. Nat. Appl. 36: $58-64$.

Fitch, A. 1858. Fourth report on the noxious, beneficial, and other insects of the state of New York. Trans. N.Y. Agric. Soc. 1858: 687-814.

Gates, D. M. 1993. Climate change and its biological consequences. Sinauer, Sunderland, MA.

Gory, M. H., and M. A. Percheron. 1833. Monographie des Cétoines et Genres Voisins, Formant, dans les Familles Naturaelles de Latreille, La Division Des Scarabées Mélitophiles. Paris, France.

Harpootlian, P. J. 2001. Scarab beetles (Coleoptera: Scarabaeidae) of South Carolina. Biota South Carolina 2: $1-157$.

Harris, T. W. 1833. Part IV. A catalogue of the animals and plants in Massachusetts, Section VII. In E. Hitchcock [ed.], Report of the geology, mineralogy, botany, and zoology of Massachusetts. Amherst, MA.

Hedin, M. C. 1997. Speciational history in a diverse clade of habitat-specialized spiders (Araneae: Nesticidae: Nesticus): inferences from geographic-based sampling. Evolution 51: 1929-1945.

Heer, O. 1862. Beiträge zur Insektenfauna Oeningens. Coleoptera, Geodaphagen, Hydorcanthariden, Gyriniden, Brachelytren, Clavicornen, Lamellicornen und Buprestiden. Natuurkundige Verhandelingen van de Hollandsche Maatschappij der Wetenschappen te Haarlem 16: $1-90$.

Hinton, H. E. 1930. Observations on two California beetles. Pan-Pac. Entomol. 7: 94-95.

Horn, G. H. 1870. Contributions to the coleopterology of the United States. Trans. Am. Entomol. Soc. 3: 69-97.

Horn, W., and I. Kahle. 1935. Über entomologische Sammlungen, Entomologen und Entomo-Museologie (Ein Beitrag zur Geschichte de Entomologie), part 1. Entomologische Beihefte aus Berlin-Dahlem. 2: 1-160.

[ICZN]. International Commission on Zoological Nomenclature. 1999. International Code of Zoological Nomenclature, 4th ed. International Commission on Zoological Nomenclature, The Natural History Museum, London, United Kingdom.

Kirby, W. 1827. A description of some new genera and species of petalocerous Coleoptera. Zool. J. 3: 145-158.

Kolbe, H. J. 1897. Beiträge zur Kenntniss melitophilen Lamellicornier (Coleoptera). Die afrikanischen Genera und Spezies der Valgiden. Stettin. Entomol. Zeit. 58: 184215.

Kolbe, H. J. 1904. Gattungen und Arten der Valgiden von Sumatra und Borneo. Stettin. Entomol. Zeit. 65: 1-57.

Krajcik, M. 1999. Cetoniidae of the World: Catalogue-Part II. Privately published by author. Most, Czech Republic.
Kraatz, G. 1883. Ueber die Gattung Valgus und eine Anzahl neuer Arten derselben. Deutsche Entomol. Zeitschrift 26: 373-379.

Krell, F.-T. 2000. The fossil record of Mesozoic and Tertiary Scarabaeoidea (Coleoptera: Polyphaga). Invertebr. Tax. 14: 871-905.

Krikken, J. 1978. Valgine beetles: a preliminary review of the genera, with descriptions of two novelties. Zool. Mededelingen 53: 154-164.

Krikken, J. 1984. A new key to the suprageneric taxa in the beetle family Cetoniinae, with annotated lists of the known genera. Zool. Verhandelingen 210: 38-43.

Krikken, J. 1986. Provisional checklist of the Valginae (Coleoptera: Cetoniidae). Haroldius 1: 1-17.

Lemdahl, G. 1990. Ett subfossilfynd av bladhorningen Valgus hemipterus från Skåne [A subfossil record of Valgus hemipterus (L.) (Coleoptera) from Scania, South Sweden]. Entomol. Tidskrift. 111: 99-100.

Leng, C. W. 1920. Catalogue of the Coleoptera of America, North of Mexico. John D. Sherman, Jr., Mount Vernon, NY.

Linnaeus, C. 1758. Systema naturae per regna tria naturae secundum classes, ordines, genera, species, cum characteribus, differentiis, synonymis, locis, ed. 10, vol. 1, Stockholm, Sweden.

Linsley, E. G., and C. D. Michener. 1943. Observations on some Coleoptera from the vicinity of Mt. Lassen, California. Pan-Pac. Entomol. 19: 75-79.

Linsley, E. G., and E. S. Ross. 1940. Records of some Coleoptera from the San Jacinto Mountains, California. PanPac. Entomol. 16: 75-76.

Mahar, J. 1989. A new location for Valgus hemipterus (Coleoptera: Scarabaeidae). Great Lakes Entomol. 22: 55.

Mahar, J., and M. P. Oemke. 1981. A North American record for Valgus hemipterus (Coleoptera: Scarabaeidae) and information on its life cycle. Great Lakes Entomol. 14: $77-79$.

Medvedev, S. I. 1969. On the larvae of Valgus hemipterus L. (Coleoptera: Scarabaeidae). Entomol. Rev. Univ. Khar'kov 48: 100-101.

Melsheimer, F. E. 1853. Catalogue of the described Coleoptera of the United States. Washington, DC

Morón, M. A., B. C. Ratcliffe, and C. Deloya. 1997. Atlas de los Escarabajos de México. Coleoptera: Lamellicornia. vol. I Familia Melolonthidae. Sociedad Méxicana de Entomología, A.C., Xalapa, Veracruz, Mexico.

O'Brien, M. F., and A. M. O'Brien. 1994. Valgus hemipterus (Coleoptera: Scarabaeidae)-another Michigan county record. Newsl. Mich. Entomol. Soc. 39: 4.

Olivier, A. G. 1789. Entomologie, ou Histoire Naturelle des Insectes, avec leur caracteres generiques et specifiques, leur description, leur synonymie, et leur figure enluminee. Colepteres I. Sec. 6, pars 84. Paris, France.

Palisot de Beauvois, A.M.F.J. 1807. Insectes recueillis en Afrique et en Amérique, dans les royaumes d'Oware et de Benin, à Saint-Domingue et dans les États-Unis, pendant les années 1786-1797. Livr. 4: 57-72. Paris, France.

Paulian, R., and J. Baraud. 1982. Faune des Coléoptères de France. II. Lucanoidea et Scarabaeoidea. Editions Lechevalier, Paris, France.

Ratcliffe, B. C. 1991. The scarab beetles of Nebraska. Bull. Univ. Nebr. State Mus. 12: 1-333.

Ratcliffe, B. C. 2002. Chapter 34-VI. Cetoniinae Leach 1815, pp. 67-71. In R. H. Arnett, M. Thomas, P. E. Skelley, and J. H. Frank [eds.], American beetles, volume 2. CRC, Boca Raton, FL. 
Ricchiardi, E. 1996. Notes on Philippines Dasyvalgus (Coleoptera, Cetoniidae, Valginae, Valgini). Boll. Museo Reg. Scienze Naturali, Torino 14: 365-377.

Ricchiardi, E. 2000. Revisione tassonomica del genere Oreoderus Burmeister, 1842, con descrizione de undici nuove specie (Coleoptera Cetoniidae Valginae). Ann. Museo Civico di Storia Naturale "G. Doria". 93: 507-557.

Riley, E. G., and C. S. Wolfe. 2003. An annotated checklist of the Scarabaeoidea of Texas (Coleoptera). Southwest. Entomol. Suppl. 26: 1-37.

Ritcher, P. O. 1945. North American Cetoniinae with descriptions of their larvae and keys to genera and species (Coleoptera: Scarabaeidae). KY Agric. Exp. Stn. Bull. 476: 1-39.

Ritcher, P. O. 1958. Biology of Scarabaeidae. Annu. Rev. Entomol. 3: 311-344.

Ritcher, P. O. 1966. White grubs and their allies. Oregon State University Press, Corvallis, OR.

Sawada, H. 1941. The Valginae of the Japanese empire. Report II. Nippon no Kochu, Tokyo 1941: 1-14.
Schaum, M. 1849. Observations critiques sur la famille, des Lamellicornes Mélitophiles. Ann. Soc. Entomol. Fr. (Ser. 2) $7: 241-295$.

Schenkling, S. 1921. Scarabaeidae: Cetoniinae. Coleopterorum Catalogus. 75: 1-431.

Schenkling, S. 1922. Scarabaeidae: Trichiinae, Valginae. Coleopterorum Catalogus. 75: 1-58.

Scriba, L. G. 1790. Verzeichnis der Insekten in der Darmstadter Gegend. J. Liebhaber der Entomol., herausgegeben von Ludwig Gottlieb Scriba 1: 40-73.

Sharp, D., and Muir,F.A.G. 1912. The comparative anatomy of the male genital tube in Coleoptera. Trans. Entomol. Soc. Lond. 1912: 477-642.

Wheeler, Q. D., and N. I. Platnick. 2000. The phylogenetic species concept, pp. 55-69. In Q. D. Wheeler and R. Meier [eds.], Species concepts and phylogenetic theory. Columbia University Press, New York

Received 26 April 2004; accepted 15 June 2005. 
Authors may post electronic reprints of their own journal articles after an embargo period of two years has passed from the date of publication. Also, authors must include on the electronic reprint the following statement:

This article is the copyright property of the Entomological Society of America and may not be used for any commercial or other private purpose without specific written permission of the Entomological Society of America.

http://www.entsoc.org/pubs/publish/copyright/index.htm 